\title{
A Persistent Fascination: Recent Publications on the Work of W.G. Sebald
}

\author{
MARKUS ZisSELSBERGER \\ University of Miami
}

\author{
Beschädigtes Leben. Erzählte Risse. W.G. Sebalds poetische Ordnung des \\ Unglücks. \\ Von Claudia Öhlschläger. Freiburg: Rombach, 2006. 258 Seiten. €38,00.
}

\section{Reading W.G. Sebald: Adventure and Disobedience.}

By Deane Blackler. Rochester, NY: Camden House, 2007. xv + 255 pages. $\$ 75.00$.

\section{W.G. Sebald: Image, Archive, Modernity.}

By J.J. Long. New York: Columbia University Press, 2007. ix +210 pages. $\$ 35.00$.

\author{
Eine fremdartige Klage \\ Und ein Verwundern daß es \\ Traurigkeit gibt—die eigene \\ Niemals die fremde derer die leiden \\ Derer die ein Recht darauf haben \\ —W.G. Sebald, "Bleston"1
}

In December 2007, I was boarding a flight to Chicago to attend the annual convention of the Modern Language Association. As I was about to take my seat in the back of the plane, I looked down the aisle where many passengers were busy stowing their luggage and taking out personal belongings before taking their seats. Several of them had taken out books, and I noticed that two of them had a copy of Austerlitz, W.G. Sebald's last prose text, in their hands, one the English edition, the other the German original. Such a coincidence 
may not be that unlikely on an airplane headed to the city hosting one of largest annual gatherings of professional readers; nor will it seem strange to those familiar with Sebald's texts, which are often organized around precisely such chance encounters and uncanny resemblances. Nevertheless, the encounter highlights a seemingly trivial fact: Sebald readers and aficionados are everywhere, testifying to a persistent fascination that his work continues to exert on readers, academic and non-academic alike. There is, at the moment, no indication that this fascination is waning. Scholarly studies about Sebald continue to be published at an astonishing pace. His writing has been the subject of numerous conferences and of a considerable body of academic articles, essay collections, monographs, ${ }^{2}$ exhibitions,${ }^{3}$ and even sophisticated online-blogs. ${ }^{4}$ More recently, it has also inspired writers and visual artists to create artworks that employ "Sebaldian" methods. ${ }^{5}$ In addition, the recent publication of previously unpublished German-language poems from his literary estate- $\ddot{U} b e r$ das Land und das Wasser. Ausgewählte Gedichte 1964-2001-will likely generate more interest in Sebald as a prose poet (see note 1).

One explanation for this readerly fascination might in fact be Sebald's combination of an innovative and hybrid writing style with an exploration of topics that continue to be of relevance in our contemporary culture, including the relationship among memory, history, and historiography; visual and memorial culture; intertexuality and intermediality; and the ethical challenges of commemorative practices in the twenty-first century. While Sebald's critical engagement with these topics rightly establishes the intellectual significance of his writing project, it does not necessarily fully explain our fascination with his work. After all, Sebald was certainly not the only German-language writer to explore these topics, nor was he the first to combine literary genres, use a variety of modern and postmodern literary techniques, and include photographs in his texts. It is questionable, then, whether the thematic orientation of Sebald's œuvre or its stylistic hybridity, however innovative, really suffice to explain the enormous enthusiasm with which readers continue to respond to his writing. That we might do well to distinguish between a readerly fascination with Sebald and an intellectual interest in his work is perhaps suggested by the expressions of amazement with which many readers have responded to his writing, a reaction exemplified by Susan Sontag's frequently quoted response to her first reading of Die Ausgewanderten: "I have never read anything like it." It seems that when it comes to explaining what Scott Denham has called the "Sebald phenomenon," " an appeal to themes and style will only take us so far and at some point must, strangely enough, give way to wonder and a certain speechlessness. The question, then, remains: why are we so fascinated with Sebald's writing, with his pursuit of the traces of individual life-stories and his melancholy meanderings into the landscapes of twentieth-century European cultural history? Why are we so attracted to the work of a particular literary imagination at a time when the relevance of literature continues to 
be contested? To what particular sensibility of the twenty-first-century reader does the work of this storyteller appeal?

The three volumes that are the subject of this review-one a British monograph, one a German collection of previously delivered university lectures, and one a revised English-language dissertation - all provide different answers to these questions. They first and foremost testify to an enduring interest in Sebald's writing and continue to examine themes in his texts that have proven particularly attractive to readers: the relationship between reality and art, between documentation and fictionalization; the poetic principles that inform the archaeological memory work of Sebald's narrators; and the role of photographs and the significance of text-image relations more generally. However, they also reflect the desire to make sense of the "Sebald phenomenon" by placing his work in broader discursive contexts. J.J. Long sees in Sebald's writing a Foucauldian engagement with modernity, while Claudia Öhlschläger reads it as a poetic version of the critique of Enlightenment articulated by Adorno and Horkheimer. Deane Blackler, on the other hand, views Sebald's work as a postmodern form of literature that calls for an undisciplined and "disobedient" reader willing to cross the boundaries of the text and follow the trajectories suggested by his or her own imagination. These arguments translate into fundamentally different approaches that pit the more conventional, objective scholarly studies by Öhlschläger and Long against the essayistic, experimental, and more intuitively guided reflections by Deane Blackler. Taken together, these publications demonstrate new possibilities for historicizing and theoretically framing Sebald's work but also show the continued difficulty of engaging with a literary imagination that encourages aesthetic border-crossings and subjective investments and in this sense poses challenges for the academically-trained reader.

\section{I}

Claudia Öhlschläger attributes the readerly fascination with Sebald primarily to the frequently noted self-reflective character of his texts. Her book Beschädigtes Leben. Erzählte Risse. follows in the footsteps of previous scholarship insofar as it presents Sebald's body of writing as a particular form of literary memory work. The first chapter delineates the elements of this Gedächtniskunst through a close and insightful reading of a short, lesser-known prose text by Sebald, demonstrating that his work is concerned primarily with the commemorative function of literary writing and its role in the construction of cultural memory. Central to this commemorative function is the relationship between fact and fiction as well as the insight that all representation involves a degree of distortion. As announced in the title of the book, Öhlschläger's argument is that Sebald's writing consistently thematizes the tension between the destruction of natural and individual life-Adorno's "beschädigtes Leben"- 
and the limits of its Darstellung in art, that is, the "Risse" inevitably inscribed in all representation. On the other hand, Sebald mobilizes this gap for "eine Poetik der Unschärfe" (53), a poetics in which distortion and falsification become "Mittel der Bewahrheitung" designed to show "dass jede Form der Beglaubigung den Weg von Verstellung und Entstellung beschreiten muss" (21). Such a poetics amounts to an "archaeology of destruction" in which remnants of history are not only recovered but also rearranged by the writer to reveal heretofore unknown historical relations and constellations. This archaeological practice of writing contains a self-reflective element insofar as the writer draws attention to the tools with which he writes history. ${ }^{8}$ Sebald's writing, then, can be understood as "eine Reflexion auf die Bedingungen der Darstell- und Lesbarkeit von Wirklichkeit im Medium des Poetischen" (35). The subsequent chapters of the book examine this poetics in its relation to a wide range of themes, including the relationship between reality and fiction, the significance of repetition as a figure for both trauma and narratability, as well as the role of travel, place, and spatiality in the construction of memory. Since the chapters are somewhat inconsistently organized - sometimes around a theme, at other times around a specific text-the subsequent overview emphasizes the linkages between the chapters instead of discussing them solely in chronological order.

Chapters two and five investigate the relationship between traumatic histories and fiction in Die Ausgewanderten, focusing primarily on intertextuality and repetition in the narrator's reconstruction of the individual life stories of four emigrants. Both chapters argue that the premise for all four stories is the émigrés' inability to cope with traumatic experiences of dislocation whose symptoms persist in the present. According to Öhlschläger, Sebald uses textual and visual material to create narratives that mark the gap in the subject's memory, resulting in a structure of repetition that mimetically reflects the incessant Wiederkehr of traumatic experiences. Thus, the protagonists' incommensurable experiences find their analog in a set of narrative portraits which Sebald deliberately leaves "unscharf."

Chapters three and four suggest that both the writings of Stendhal and the paintings of Jan-Peter Tripp served as a theoretical inspiration for this "Poetik der Unschärfe." Sebald's essay on the painter can be read "als Formulierung einer Repräsentationstheorie" (53) insofar as Tripp's quasi-photographic paintings show that authenticity is merely artificial, a product of deception, and that therefore "jede Darstellung die imaginativen Bedingungen seiner [sic] Realisation mitbedenken muss" (56). The need for reality to be supplemented by art is also at the center of Stendhal's theory of "crystallization," which Sebald mobilizes in Schwindel. Gefühle. to illustrate the inseparability of historical truth and artistic imagination. As in the case of Tripp, Sebald learns from Stendhal how to use "Verfremdungen und abstrakte Störungen des Mimetischen" to produce reality effects (66). 
Chapter six examines Sebald's relationship to Austrian writer and Holocaust survivor Jean Améry, returning once again to the question of how the traces of a traumatized interiority can be represented in writing. Focusing on the intertextual references to Améry's internment at the fortress Breendonk in Austerlitz, Öhlschläger proposes that Sebald seeks to approach Améry's traumatic experiences by staging the narrator's passage through an Erinnerungsraum in which various "Bild- und Erinnerungsschichten" overlap rather than through a chronological narrative (108). The result of this spatial memory is the elimination of the distance "zwischen dem Zeitzeugen und dem Zeugen der nachfolgenden Generation" (109), an important observation whose potential ethical problems Öhlschläger unfortunately does not further investigate.

In chapters seven and eight Öhlschläger focuses on spatiality and temporality to analyze the structural relationship between individual life stories and the broader cultural history in Austerlitz. Drawing in part on Foucault's writing on power and disciplinarity, Öhlschläger argues that Austerlitz, in its extended reflections on architectural history, presents individual suffering as inseparably intertwined with the network of violence inscribed in architectural structures like the fortress at Breendonk or the Palace of Justice in Brussels. The text juxtaposes these "Topographien der Gewalt" (111) in which the historical traces of destruction become legible with the inherent illegibility of individual trauma which requires the imaginative investment of the narrator for its reconstruction.

Chapter nine mobilizes Foucault's notion of "heterotopia" and Marc Augé's concept of "non-places" to examine the nature of space and spatiality and their relationship to travel in Austerlitz and "All'Estero," the second narrative of Schwindel. Gefühle. It suggests that in their travels through waiting rooms, airports, train stations, and libraries, Sebald's narrators frequently traverse both "heterotopias" and "non-places," the latter designating places through which individuals pass but in which they no longer dwell, the former describing liminal spaces that contain and make visible what society excludes. Sebald's texts expose such sites as fundamentally implicated in the constitution of the social and in the formation of subjectivity, thus revealing them as essential features of modernity.

The nature and function of melancholy in Die Ringe des Saturn is the focus of both chapters ten and eleven. The melancholy mood that permeates Sebald's texts is, on the one hand, the affective expression of a writing that constructs the history of civilization as a natural history of destruction and cultural decline. On the other hand, it also serves as the driving force behind a literary critique of civilization that takes its cue from Benjamin's angel of history and looks backwards "um die Verfallsgeschichte der Moderne vom Ursprung ihres Fortschrittversprechens her zu lesen" (177). On the narrative level, this melancholy disposition finds its corresponding tool in bricolage, 
Sebald's poetic method, adopted from Claude Lévi-Strauss, in which heterogeneous textual and visual materials are combined to reconstruct the past.

Sebald's lectures on the air war and German literature are the subject of chapter twelve. Focusing in particular on Sebald's literary description of the destruction of Hamburg in Luftkrieg und Literatur, the analysis suggests that the account is marked by the tension between emotionless documentation and mimetic "einfühlender Beschreibung" (198). Öhlschläger aptly observes that the lectures at times insist on "die Veranschaulichung des Schreckens" (199), a feature that distinguishes them from Sebald's other prose texts where the narrator is more careful to maintain distance vis-à-vis the horrors of history. Like Julia Hell in her insightful analysis of "horror" in Luftkrieg und Literatur, ${ }^{9}$ Öhlschläger recognizes Sebald's affective investment as a problematic dimension of the lectures but does not pursue this insight any further.

Chapters thirteen and fourteen examine the theme of a gradually disappearing world in the prose poem Nach der Natur and as a recurring trope in the work of Adalbert Stifter, Thomas Mann, and Max Frisch. In the three male portraits of the poem, Sebald offers a depiction of nature that is both apocalyptic and artificial. Thus, the poem's title has a double meaning, referring to both the end result of an entropic process in which nature has turned into pure catastrophe and the realization that even when nature is alive, art can represent it only artificially, in a state of mortification, as natura morte. This conception of nature is exemplified in particular by the paintings of Matthias Grünewald which figure as "Allegorien einer sich an sich selbst verzehrenden Welt, als Allegorien eines Schwindens" (211). Öhlschläger shows that the preoccupation with "dem Schwinden der Dinge" is also at the heart of Stifter's writing, where it appears as a potential "Einbruch des Weißen" and points to the fear of a "Entleerung und Entmaterialisierung der Welt" (218). In one of the first more substantial discussions of Sebald's relationship to Stifter, Öhlschläger proposes that Sebald's project can be understood as an inversion of Stifter's narratives: where Stifter mortifies nature in order to preserve it, Sebald's reanimates the material remnants of catastrophe in the gaze of the melancholy observer. In this sense, Sebald mobilizes Stifter's poetics for a contemporary ethics of remembrance.

The last chapter takes up the frequently discussed question of whether Sebald's work should be regarded as modern or postmodern. Öhlschläger argues that it includes both modern and postmodern elements, the latter being characterized by the use of intertextuality, the deliberate interruption of narrative linearity, and the presentation of human history as a "kultureller Verfallsprozeß" (237). On the other hand, Sebald's engagement with writers like Stifter, Robert Walser, and Kafka indicates his indebtedness to a modern literary tradition. Öhlschläger concludes here with the intriguing observation "dass Sebald eine Sympathie für traumatophile Schriftsteller gehegt habe" (241), thus implicitly pointing to an area of Sebald's writing that has so far received 
rather limited attention, namely his work as a literary scholar and essayist and the rather peculiar subjective investments that mark his work as a reader.

Beschädigtes Leben. Erzählte Risse offers close, sophisticated readings of Sebald's texts and demonstrates the fruitfulness of placing his œuvre into broader discursive contexts that include the work of Benjamin and Foucault, as well as Adorno and Horkheimer, even though the significance of the latter's critique of Enlightenment for Sebald's work remains implied and would deserve more substantial elaboration. In addition, the intellectual merits of the book are somewhat undermined by an imbalanced chapter development and presentation, most likely a result of the fact that the chapters were originally delivered as university lectures and in a few cases are simply too short and insubstantial to serve as "chapters." To be fair, Öhlschläger makes clear in the preface that the "mündliche Gestus" and the "lockere Fügung" of argumentation inherent in the lectures were retained on purpose. However, such a decision becomes problematic if it is also used as an excuse not to engage with existing work on Sebald, here in particular with Anglo-American scholarship. The goal of her engagement with Sebald's text is, as she immediately adds, not "die vorgebrachten Thesen mit schon existierenden Forschungsarbeiten abzugleichen oder gar ihre Beweiskraft auf den Prüfstand zu stellen"; instead, she aims for "Annäherungen an das Werk eines Autors, die sich einem close reading verdanken, Sebalds Texte aber auf verschiedene theoretische Horizonte hin öffnen [ . . . ]" (9). While the "Abgleichung" of others' thinking with one's own should of course not be the purpose of scholarly writing, some of the "close readings" in the book would have deserved an Auseinandersetzung with relevant research. Öhlschläger's otherwise thoughtful engagement with Sebald's work in this way also points to a broader problem in Sebald scholarship: the tendency of some scholars not to critically engage with previous research (as opposed to simply citing it in footnotes) and, more particularly, the apparent reluctance of national disciplines to "look beyond [their] borders to a greater international context and community of scholars," as Lynn Wolff aptly observed in an earlier review of research on Sebald. ${ }^{10}$

\section{II}

Claudia Öhlschläger's book emphasizes the strong "appellative character" of Sebald's writing in which the reader is asked to take on the role of an interpreter (191). The question of how Sebald's texts actively involve the reader in the constitution of meaning is the subject of Deane Blackler's revised dissertation Reading W.G. Sebald: Adventure and Disobedience. Inverting Umberto Eco's notion of the "obedient reader," Blackler argues that Sebald's œuvre demands a "postmodern" reader, one who is willing to be "disobedient" and follows interpretive paths that lie outside the boundaries of the text (ix). Intriguingly, the book suggests that the main theme of Sebald's texts is the activity of read- 
ing itself and the way literature can and should engage the reader's imaginative capacities. Thus, Blackler views some of the most prominent elements of his writing - the use of a quasi-autobiographical narrator, the integration of photographs into the text, and what she calls the representation of place as "poetic space" ( $\mathrm{x}$ - —as designed to alienate the reader and unsettle his or her interpretive sensibilities. In challenging these sensibilities, Sebald's texts offer us more than just a "natural history of destruction" or a critique of modern civilization from the standpoint of a melancholy observer; rather, they describe a mode of relating to the world that is marked by "wonder" and allows for the possibility of "mystery" (x). In this conception of experience, reading emerges as an activity with a didactic end, as the means to a learning that may counter "our natural tendency to destruction" (x). In accordance with her arguments, Blackler presents us with a somewhat idiosyncratic and esoteric reading of Sebald that is guided less by methodological considerations or scholarly conventions and more by reflections on her own "adventures" and experiences in reading Sebald's texts. The results are at best mixed: while the book as a whole advances a convincing argument, it tends towards excessive repetition instead of further developing its argument through close readings of the texts.

The study consists of three chapters, an extended introduction, and a brief conclusion. The introduction reflects on the origins of the project and situates Sebald in literary history. Reading Sebald alongside the work of Roland Barthes, Italo Calvino, Umberto Eco, and Wolfgang Iser, Blackler argues that Sebald's work is essentially "postmodern" insofar as it calls for a Barthesian "writerly" reader who, as a collaborative author, participates in the construction of the text. To that end, Sebald's writing exploits the gaps between documentation and fiction that are akin to the "cuts" produced by Alexander Kluge's practices of "montage," thereby creating spaces in which the reader must exercise his or her own imagination "in a manner typical of postmodern reading" (2). After outlining this argument, the introduction concludes with a review of previous research that-perhaps as a remnant of a former dissertation that tries to catch up with a rapidly growing body of scholarship- unfortunately reads like an addendum insofar as it is not used for the development of the book's arguments. The introduction also already foreshadows a problem that permeates the entire text, namely the author's propensity to excessively repeat herself.

Chapter one takes as its starting point a reflection on the Gospel of Luke and the problem of biblical hermeneutics posed by this text, to which Blackler had turned intuitively after hearing a man commenting on the "literariness" of scripture read by a child in church. Blackler proposes that the Gospel exemplifies the tension between an "obedient" and a "disobedient" reading, between one that views it as an authentic historical account, and one that sees it as a literary "story" open to interpretation. In Sebald's work, this tension is reflected in the combination of documentation and fiction. By creating narratives that 
blur the distinction between history and fiction and foreground their own artificiality, Sebald subverts the authority of the text, transferring it to the reader and forcing him or her into a "writerly" position in which he or she must take on the role of an active interpreter (48).

Chapter two provides a lengthy discussion of Sebald's biography, his life as an academic and literary scholar, his development as a writer, and the responses by colleagues and critics to his work. Drawing primarily on Sebald's interviews and statements by critics, Blackler traces the starting point of his writing project back to his German origins, his family history, and his postmemorial relationship to the German past. This is followed by an account of his academic education and career, his subsequent acceptance of a position at the British University of East Anglia in Norwich, his relationship to academia, and his gradual turn to fiction writing. The purpose of this chapter is ostensibly to locate moments of "disobedience" that laid the foundation for Sebald's later writing and expectations from his readers. While Blackler's presentation of Sebald's life and emergence as a writer is detailed and compelling, it is also highly descriptive and not sufficiently mobilized for the development of the book's argument. In fact, the biographical account seems to serve merely as an occasion to repeat the argument of the book instead of developing it. In addition, the conclusion of the chapter returns to a further review of scholarship in Sebald, thus once again highlighting Blackler's tendency to describe previous research rather than using it more effectively to develop her own reading. The result, then, is a chapter that, contrary to the author's assertion, does not really "engage with the task of establishing a critical position" from which to read Sebald's writing (ix) and instead provides biographical information that by now will be well known to Sebald readers.

Chapter three is the strongest part of the book insofar as it refocuses on developing the actual argument through a close engagement with Sebald's texts. Divided into three parts, the chapter examines how Sebald elicits readerly disobedience in his major prose texts through the use of a traveling narrator, the insertion of photographs, and the construction of space. In the first part, Blackler shows that the reader's engagement with the text is mediated by a narrator whose travels and reflections consistently mark the "literariness" of the text, thus preventing the reader from simply accepting what is presented as an historical account. Sebald's narrators, then, always traverse two separate but intertwined "worlds," one that is the fiction of the narrator's "real" travels, the other the "real" world marked as fiction. In this sense, the narrators exemplify the kind of reader Sebald wants for his texts, a reader who is "free to locate his or her own position transgressively, both inside and outside the textual economy" (94). Apart from the actual travels undertaken by the narrator, the reader is always being asked to take into account "the writing journey of the text's production [ ... ] and in so doing, step a little away from the thralldom of the narrator's voice and the imperative of his itinerary" (99). 
The functions of black-and-white photographs, too, need to be considered in the contexts of the texts' hyperrealism and self-reflexivity, as Blackler argues in the second part. Rather than serving a documentary function, the photographs bear "witness [ . . ] to the fictional process itself" (146). Their strategic placement in the text aims at alienating the reader and motivating him or her to disobediently reflect on their role inside and outside of Sebald's writing. The Verfremdungseffekt produced by the photographs is in part the product of the manipulative interventions by a narrator who strategically withholds meaning or offers a reading that highlights the gap between text and image, in both cases making the photograph's referentiality undecidable. The photographs are thus not documents but rather discursive constructs, "fusion text[s]" in whose interpretation the viewer must participate as a disobedient "reader" (139).

The third part of the chapter suggests that much like the photographs, "places" in Sebald's texts are "discursively constructed" spaces in which geographical places merge with topographies of the mind to create a particular "poetic space." In her illuminating discussion of Austerlitz, for instance, Blackler shows that the text is a complex construction of such poetic space while being narratively anchored in meticulously indexed geographical places. The chance meetings between Austerlitz and the narrator are tied to specific places such as train stations and museums whose history in turn is thematized in Austerlitz's architectural studies. The text transforms such places into spatial palimpsests, giving way to a "diffused sense of space" in which the protagonist's traumatized interiority merges with external topographies and in which travel is consequently not just physical, but also textual and imaginary. This "poetic space," too, Blackler sees as a part of a hyperrealism that strives for a "dialogical" engagement with the reader, destabilizing the latter and encouraging him or her to veer "away from the narrator's side for her own imaginative and contemplative purposes" (187).

Reading W.G. Sebald: Adventure and Disobedience is an essayistic reflection on a reading experience rather than a scholarly study and in this sense offers an engagement with literature that is reflective of the argument it advances: that Sebald's writing calls for a "disobedient" and emancipated reader willing to digress and deviate from the text and imaginatively and critically explore the spaces opened up by Sebald's self-reflective hyperrealism. While Blackler's insights into Sebald's work are not fundamentally new or original, her willingness to approach Sebald "adventurously" and somewhat intuitively makes this a text that perhaps nevertheless tells us more about our fascination with Sebald than the more "scholarly" ones reviewed here. After all, Blackler makes bold claims about our readerly sensibility, noting that reading Sebald might, as in her case, lead to "a renewed awareness of the capacity of literary fiction at the end of the millennium to engage the reader's imagination and thoughtfulness" (16). 
For Blackler, then, the fascination with Sebald's writing project stems primarily from the latter's appeal to the reader to exercise his or her own imagination and its "ambition to refocus the art of reading at the end of the ever-accelerating twentieth-century" (ix). This is a powerful argument that echoes much of Sebald's own essayistic engagement with literature, which tends to defy scholarly conventions and insist on imaginative and subjective investments as a precondition of reading and literary criticism. Such an essayistic and subjective engagement with literature packaged as an "academic" study, however, could be perceived as being at odds with scholarly conventions and point to a potential conflict between the "disobedient" reader and academic "protocols of reading" (6), one that is best illustrated by Sebald's own antagonistic relationship to Germanistik and his turn away from academic writing later in his life. As Blackler herself intriguingly observes, Sebald was "a disobedient" academic and literary scholar (66). Such an observation would have invited, especially in a book concerned mainly with reading, a closer examination of Sebald's early scholarly work on Döblin and Sternheim and his later literary essays, which unfortunately are discussed only very little. Here, then, is also where some of the limitations of Blackler's exclusive work with the English translations manifest themselves: although Blackler rightly observes that "the experience of Sebald in translation is so rich and rewarding that it also merits consideration" (8), the focus solely on translated texts can result in significant omissions.

\section{III}

In his monograph W.G. Sebald: Image, Archive, Modernity, J.J. Long proposes that the many different themes of Sebald's texts—ranging from the Holocaust, trauma, and Heimat to photography and intertextuality — can be understood as being part of a broader set of questions and problems related to modernity. By "modernity" Long refers primarily to a range of social, cultural, political, and economic changes in Europe starting in the eighteenth century. Central to this conception of modernity is the role of the image and, more particularly, the archive, which for Long encompasses a wide range of institutions and practices of collecting. Long contends that such archival institutions and practices are also a central concern of Sebald's work, which explores their role in the preservation, remembrance and transmission of the past, and in the formation of subjectivity.

In this respect, Sebald's writing also testifies to an engagement with the work of Michel Foucault, whose reflections on disciplinarity, surveillance, and power/knowledge relations serve as the theoretical framework of Long's study. The book suggests that Sebald's engagement with Foucault reflects the 
ambivalence that marks Sebald's relationship to modernity more generally: while Sebald highlights the complicity of archival practices in the disciplinary regimes of modernity, he also maintains a belief in the autonomy of the subject and in the possibility of resisting these regimes. The book investigates this ambivalence in two parts (together with the introduction and conclusion, there is a total of nine chapters). Part one is thematically organized around the archive, the photograph, and discipline, while part two further expands the discussion of these themes in separate analyses of each of Sebald's major prose texts.

Chapter two examines the various forms of collections found in Sebald's work. Starting with a discussion of the changes in practices of collecting that gave rise to the modern museum, the chapter highlights ways in which institutionalized forms of collecting are implicated in the power/knowledge relations characteristic of modern societies. Following Foucault, Long argues that the transformation of the collection was characterized not only by fundamental shifts in epistemes but also by a reordering of space that reveals to what extent the museum participates in the "regime of surveillance" (31). Against the background of the museum's disciplinary qualities, Long reads the representations of museums in Sebald's texts as "a way of addressing distinctly modern questions of power, knowledge, and subject-formation" (32). Through his engagement with Thomas Browne, Sebald offers an "archaeology of the collection" that demonstrates how in the display of natural phenomena the viewer is posited as both subject and object of knowledge. In Austerlitz, on the other hand, the exhibitions of nature in Naturalienkabinette and zoos betray a certain uncritical fascination with the collection while, at the same time, exposing its complicity with colonialism. Long argues that this combination of fascination and critique reflects Sebald's ambivalence towards modernity but also suggests a desire to look beyond Foucault's "totalizing" account of power for possibilities of resistance.

Chapter three turns to the topic of photographs, a feature of Sebald's writing that has proven particularly attractive to scholars. Noting that photography in Sebald's texts has so far been considered primarily in its relationship to memory, Long suggests that his texts are also concerned with photography's disciplinary function in identity formation. The passport photograph included in Schwindel. Gefühle. exemplifies the "microphysics of power" at work in the photograph insofar as it controls and regulates the movement of bodies between states and constitutes the photographed as "national" subject. The discussion of images from Die Ausgewanderten shows, however, that the photograph's participation in "regimes of power" also extends to ethnography and anthropology, implicating it in "the politics of colonialism and the construction of visual topologies of race" (51). On the other hand, the deviant postures taken on by the subjects in the group photographs of the same text 
suggest that there are possibilities for resisting the normative functions of photography. While Sebald's work in this way thematizes the disciplinary effects of photography and its role in the construction of subjectivity, Long contends that it also presents images as potential sites of resistance.

The starting point for chapter four, titled "Discipline," is the premise that the various manifestations of disciplinarity in Sebald's writing can be read against its engagement with pre-modern forms of power. Long focuses in particular on the way power is inscribed on various bodies. The thematization of Roger Casement's sexuality in Die Ringe des Saturn, for instance, can be read as a commentary on the sexualized body. According to Long, Casement's diaries are presented as an archival and confessional site that produces the "truth" of Casement's being as defined by his alleged homosexuality. Similarly, while the reconstruction of Ambros Adelwarth's life story in Die Ausgewanderten emphasizes the relationship between marginalized sexuality and the increasing deterioration of the protagonist's interiority, it also suggests that Sebald, contrary to Foucault, tends to posit sexuality as "the determining factor in the constitution of subjectivity" (75). The second part of the chapter turns to the question of how "archival technologies" such as passports, maps, and files participate in the distribution and fixing of bodies in space. Long argues that Sebald reveals maps to be fundamentally implicated in colonial ideology and shows how the creation of cartographic space aims for the appropriation and "ideological coding" of geographical space. The photograph of the Registraturkammer in Theresienstadt, on the other hand, points to a correlation between archival filing practices and the biopolitical management of the concentration-camp population.

Chapter five focuses on the relationship between memory, travel, and wonder in Schwindel. Gefühle. Starting with a reflection on the role of newspapers, Long argues that the text explores the various ways in which individual memory is increasingly replaced by the "external mnemonic technologies" that are part of the archive (99). The emergence of such an "archival consciousness" can be traced back to the nineteenth century and is highlighted in Sebald's engagement with Stendhal whose memories of historical events are repeatedly revealed as inauthentic and as based a priori on archival supplements. This "loss of authentic memory" finds its complement in the fragmentation of Erfahrung and the subject's corresponding inability to integrate his experiences into a coherent narrative. Long shows that the structure of Schwindel. Gefühle., which replaces narrative cohesion with a set of recurring motifs and patterns of repetition, reflects the very archival consciousness that it foregrounds thematically. Accordingly, Sebald's narrator traverses an immanent world marked by uncanny coincidences and isolated experiences that refuse integration into a meaningful narrative; instead "they exist as unassimilated moments of wonder" (104). The chapter proposes that Sebald, in staging such 
"moments of wonder," endows the world with a sense of the "fantastic" and in this sense seeks to counter "the fragmentation that characterizes the archival consciousness of modernity" (107).

Focusing on the four narratives of Die Ausgewanderten, chapter six examines the role of photography in the transmission of traumatic experiences of exile and dislocation. It argues that the problem of transmission should be understood in its relationship to the archive insofar as memory is passed on through archival technologies that are individual and familial rather than institutional, such as the diary, letters, and family albums. Long then poses the question of how such archives function in power relations and in the way knowledge about the emigrants' lives is produced and disseminated. The answers to this question are inevitably linked to the narrator's status as a second-generation witness. Long demonstrates that the narrator's postmemorial knowledge of the various protagonists consists of a combination of narratives passed on by others and the narrator's "fantasy interpretations" of family archives (122). The family album is an essential component of these archives insofar as it mediates the relationship between narrative and interpretation: the viewing of the images provides the "impulse" for narrative while the narratives in turn caption and frame the images, which become "enveloped and fixed in their meaning by the narratives to which they give rise" (122). However, the meaning of the photographs is not only determined by the text that frames them but also by the fact that the photographs refer to each other. This "crossreferencing" establishes similarities between otherwise unrelated events and objects and therefore creates "patterns of constancy" that run counter to the fragmentation typical of modernity (126-27). According to Long, Die Ausgewanderten can therefore also be understood as a "photographic archive" that seeks to "counteract the dispersal, dissipation and rupture inherent in the history of modernity" (127).

Chapter seven returns to the significance of maps and cartographic archives and considers their relationship to travel in Die Ringe des Saturn. It argues that the disciplinary purpose of maps, and in particular, their political role in the recording and controlling of space and in the disciplining of the traveler, are crucial to understanding the text's preoccupation with walking, digression, and melancholy. While the narrator's engagement with maps and their reproduction in the text are designed to reveal their various disciplinary functions, Sebald uses the peripatetic practices of the narrator to stage a bodily performance that can potentially elude this disciplinarity. Drawing on N. Katherine Hayles's distinction between "body" and "embodiment," Long suggests that cartography exercises a normative function that abstracts the material body through its inscription in space. Sebald's narrator resists this inscription by deviating from the path prescribed by the map, thus reinserting a bodily materiality that can "subvert the map's disciplinary intention" (134). The "poetics 
of digression" that is characteristic of the text as a whole corresponds to this aimless wandering on the level of narrative. However, the structure of the text also reveals the limitations of the "embodied" walker's ability to resist the forces of modernity. Insofar as Sebald constructs a natural history of destruction in which it is difficult to qualitatively distinguish one event from another because they are all presented as equally "catastrophic," the text reveals itself as structured on a principle of "metaphorical similarity and substitutability" (143) that potentially reinscribes it in modernity's disciplinarity.

Chapter eight turns to Austerlitz to suggest that the text offers an exploration of "the 'archival consciousness' of the modern subject" (149). In his inability to remember the past, the protagonist Austerlitz relies, in the search for his true identity, on archival material that always proves to be fragmented. Thus, his subjectivity is essentially defined by an "archival lack" (150). Despite this lack, Austerlitz's repressed memories, which gradually return in part as a result of the confessional relationship between himself and the narrator, betray a "desire for the retrieval of an authentic self" (157). The text thus pits the hope for the restoration of an authentic subjectivity against the incompleteness of the archive: while the return of repressed memories and the recovery of remnants of the past promise to fill the archival lack, their fragmentariness constantly forces Austerlitz to return to the archive as source for knowledge. Long thereby demonstrates that the text defines Austerlitz's subjectivity not in psychological terms but rather in its relationship to the external materiality of the archive. In a broader sense, Sebald's work thus suggests that "the subject of modernity is ineluctably dependent on external mnemotechnical prostheses" (163).

W.G. Sebald: Image, Archive, Modernity is a well-researched and convincingly argued book that provides some genuinely new insights into Sebald's relationship to modernity. The strengths of the book are Long's ability to synthesize the heterogenous themes of Sebald's œuvre and to develop his arguments through a thoughtful engagement with existing research on Sebald. Of the books reviewed here, it is also the most "academic" in tone and style, highly theoretical and marked by a level of abstractness that will most likely limit its potential audience. Given its scholarly rhetoric and focus on theory, one may also wonder to what extent the book actually loses track of Sebald in the very process of approaching him. In this context it is worth recalling that Sebald himself was a trained academic and literary scholar, and that his subsequent turn to literary writing was greatly motivated by a desire to escape from the disciplinary rigidity of postwar Germanistik and the practices of an institutionalized literary criticism more concerned with "archiving" literature than with engaging with it. ${ }^{11}$ For that matter, the reader and literary scholar Sebald seems to have been more concerned with reinserting the "literary" into literary criticism than with interpretation according to scholarly conventions. ${ }^{12}$ On the one hand, the ambivalence Long detects in Sebald's relationship to 
disciplinarity and modernity more broadly might not just be a theme of his later prose writing but in fact be at the heart of his very turn to literature, a point which Long's book does not address. On the other hand, there is a certain irony in Long's study not only because its academic rhetoric and theoretical approach "discipline" Sebald's work - through its subordination to theorybut also because it replicates the kind of "scholarly" engagement with texts in which "literature" gets increasingly lost and from which Sebald therefore tried to distance himself.

\section{IV}

Sebald's appearance on the literary scene in the late nineteen-nineties was followed by the rapturous reception of his work and the rapid emergence of a body of scholarship that at first tended to be anecdotal but since then has continued to become more critical, theoretically more differentiated, and generally more specialized. For the most part, the works reviewed here confirm and reflect this development. Long's theoretically sophisticated Foucauldian study of Sebald in the context of modernity highlights Sebald's engagement with philosophy as well as his ambivalent relationship to disciplinarity and subjectivity. Yet, while the book's arguments are clear and convincing, the highly abstract Foucauldian rhetoric will make this a challenging read even for those well-versed in critical theory. Öhlschläger's reading of Sebald's work as a poetic critique of Enlightenment is a reminder that both Adorno and Horkheimer as well as Benjamin were Sebald's main "teachers" in the postwar years and strongly influenced his writing project as a whole. While Öhlschläger brings Sebald into conversation with Benjamin, the influence of Adorno and Horkheimer remains somewhat of an assertion, suggesting that there is more room for further research. Her study will find an audience particularly with those interested in the specific narrative and visual techniques as well as the theoretical foundations of Sebald's literary Gedächtniskunst.

Blackler's book was conceived at a time when Sebald scholarship had just started to emerge. While it advances a compelling argument about the postmodern strategies by which Sebald elicits "disobedience" in his readers, it also focuses on aspects of Sebald's work with which readers will by now be familiar, thus making the study somewhat dated und unlikely to be of substantial use to advanced Sebald readers. However, all studies respond to the question whether Sebald is modern or postmodern and hence testify to an increased tendency in scholarship to historicize his work. Perhaps more important for our understanding of the fascination with Sebald is both Blackler's and Long's suggestion that his texts present the individual's relationship to the world in part as one of mystery and "wonder," thus leaving room for an interpretation of Sebald's work as something other than a poetic critique of civilization and the writing of a "natural history of destruction." Moreover, Blackler's provocative 
suggestion that "reading Sebald is to be mindful of reading" itself should serve both as a challenge and inspiration to Sebald readers not only to seek a more critical engagement with his work as a literary scholar and essayist but to reflect more carefully on our own curious readerly fascination with Sebald's literary imagination.

${ }^{1}$ W.G. Sebald, "Bleston. A Mancunian Cantical," in: Über das Land und das Wasser. Ausgewählte Gedichte 1964-2001, ed. Sven Meyer (München: Hanser, 2008), 24.

${ }^{2}$ Noteworthy recent and forthcoming scholarship includes W.G. Sebald and the Writing of History, ed. Anne Fuchs and J.J. Long (Würzburg: Königshausen \& Neumann, 2007); Searching for Sebald. Photography After W.G. Sebald, ed. Lise Patt (Los Angeles: Institute of Cultural Inquiry, 2006), an extensive collection devoted to photography and text-image relations in Sebald's work; Eric Santner's book On Creaturely Life. Rilke. Benjamin. Sebald (Chicago: U of Chicago Press, 2006), a complex study with whose provocative arguments Sebald scholars have yet to engage. Recent research has also started to more closely investigate Sebald's relationship to a particularly Austrian literary and intellectual tradition. In Mobile Modernity (New York: Columbia UP, 2007), Todd Presner demonstrates that putting Sebald into conversation with Freud can illuminate Sebald's understanding of literature and the complexities of his narrative techniques; Martin Klebes offers an interrogation of the relationship between Sebald and Wittgenstein in a chapter of his Wittgenstein's Novels (New York: Routledge, 2006); the journal Modern Austrian Literature recently devoted a special issue to the topic "W.G. Sebald and Austrian Literature" (Vol. 40.4 [December 2007]).

Bettina Mosbach's published dissertation, Figurationen der Katastrophe. Ästhetische Verfahren in W.G. Sebalds Die Ringe des Saturn und Austerlitz (Bielefeld: Aisthesis, 2008) offers an examination of narratology and narrative technique in Sebald's work. Finally, Saturn's Moons: A W.G. Sebald Handbook, edited by Jo Catling and Richard Hibbitt, published by Legenda and scheduled for release on December 1, 2008, will include, among other things, reflections on Sebald's work by former colleagues and students, articles that draw on Sebald's Nachlass, and an extensive bibliography on Sebald scholarship.

${ }^{3}$ The Marbacher Literaturarchiv is currently showing an exhibition titled "Wandernde Schatten. W.G. Sebalds Unterwelt" (September 26, 2008-February 1, 2009) that includes writings from Sebald's Nachlass. See the catalogue Wanderne Schatten. W. G. Sebalds Unterwelt. Hrsg. von Ulrich von Bülow, Heike Gfrereis und Ellen Strittmatter. (Marbacher Katalog 62.) Marbach: Deutsche Schillergesellschaft, 2008.

${ }^{4}$ One of the most insightful blogs is titled "Vertigo: Collecting \& Reading W.G. Sebald." Apart from offering his own reflections on Sebald's writing, the author also frequently updates the blog with news about conferences, publications, and topics related to Sebald. It is easily one of the most thoughtful ongoing online commentaries on Sebald's work. For other substantial blogs on Sebald see, for example, http://www.wgsebald.de/ and http://www.conversationalreading .com/wg_sebald/index.html.

${ }^{5}$ Asked about his film My Winnipeg in a recent interview, Canadian film director Guy Maddin noted that he "wanted to make it like a film equivalent to a W.G. Sebald book, where he sets out on a stroll and ends up digressing and winds up in a really interesting place" (http://thephoenix .com/Providence/Movies/64453-Believe-it-or-not/). The recently published Searching for Sebald: Photography after W.G. Sebald (see note 2) includes a number of visual art works inspired by Sebald's work. For creative writing projects inspired by Sebald's narratives, see, for example, the dissertations by Andrew Prall, "No Thoroughfare" (Ph.D. diss., University of Denver, 2005) and Brenda Cockfield, "All these old things" (Ph.D. diss., Concordia University [Canada], 2004).

${ }^{6}$ Susan Sontag, "W.G. Sebald's The Emigrants," Times Literary Supplement, November 29, 1996: 15 .

${ }^{7}$ Scott Denham, "Foreword: The Sebald Phenomenon," W.G. Sebald. History-Memory-Trauma, eds. Scott Denham and Mark McCulloh (Berlin: de Gruyter, 2006), 1. 
${ }^{8}$ The notion of Sebald's work as a form of "archaeological" practice is also the subject of the collection Öhlschläger edited together with Michael Niehaus: W.G. Sebald. Politische Archäologie und melancholische Bastelei (Berlin: Erich Schmidt, 2006).

${ }^{9}$ Julia Hell, "The Angel's Enigmatic Eyes, or The Gothic Beauty of Catastrophic History in W.G. Sebald's 'Air War and Literature'.” In: Criticism 46.3 (Summer 2004): 361-92.

${ }^{10}$ Lynn Wolff, "'Das metaphysische Unterfutter der Realität': Recent Publications and Trends in W.G. Sebald Research," Monatshefte, 99.1 (2007): 82.

${ }^{11}$ Sebald frequently criticized the reading practices of Germanisten, in particular in his early academic work on Sternheim and Döblin as well as in some of his essays on Austrian literature. For Sebald's "provocative" scholarly gestures and an examination of his literary scholarship more broadly, see Ulrich Simon, "Der Provokateur als Literaturwissenschaftler. Anmerkungen zu Literaturbegriff und Argumentationsverfahren in W.G. Sebalds essayistischen Schriften," Sebald. Lektüren, ed. Marcel Atze and Franz Loquai (Eggingen: Isele, 2005), 78-104.

${ }^{12}$ On the "literary" in Sebald's literary criticism, see also Neil Christian Pages, "Crossing Borders: Sebald, Handke, and the Pathological Vision," Modern Austrian Literature 40.4 (December 2007): 61-92. 